\title{
ANALYSIS OF PUNCTURE RESISTANCE OF GEOMEMBRANES AND GEOTEXTILES
}

\author{
Mariusz Cholewa ${ }^{1}$, Tetiana Kutia ${ }^{2}$ \\ ${ }^{1}$ Department of Hydraulic Engineering and Geotechnics, University of Agriculture in Krakow, al. Adama Mickiewicza 24/28, \\ 30-059 Kraków \\ ${ }^{2}$ National University of Water and Environmental Engineering in Rivne, Institute of Automation, Cybernetics and Computer \\ Engineering, Ukraine
}

\begin{abstract}
Aim of the study

The aim of the article was to present the results of the analysis of puncture resistance of shielding and sealing geosynthetics. Standard qualification tests were carried out on a rigid support in accordance with PN-EN 14574: 2015-12. Four types of protective geotextiles with different thicknesses and weights as well as three types of geomembranes differing in thickness were used for the tests. Individual materials were examined separately, as well as in the form of geocomposites.
\end{abstract}

\begin{abstract}
Material and methods
Two groups of geosynthetics were used in the study. The first group were four types of geotextiles whose function is to separate materials with different grain sizes, or to provide filtration in engineering structures. Geotextiles were characterized by their varying thickness, basis weight, and production technology. The second group were impermeable geomembranes with sealing properties, made of smooth-rolled polyethylene on three sides, in three heights. Geosynthetics were tested for puncture resistance with a pyramid (PN-EN 14574:2015-12).

\section{Results and conclusions}

Among the geotextiles, needle-punched non-woven fabric with a thickness of $4 \mathrm{~mm}$ turned out to be the most resistant to puncture. The values for the remaining needle-punched geotextiles, $1.5 \mathrm{~mm}$ thick, depended on their basis weight and differed in strength by $30 \%$ in favour of heavier non-woven geotextile. Glued geotextile with a thickness of $0.5 \mathrm{~mm}$ were shown to have a similar strength to $1.5 \mathrm{~mm}$ geotextile with a heavier weight and $46 \%$ more durable than geotextile of the same thickness and a lower weight. In the case of geomembranes, puncture resistance turned out to be $2-5$ times higher than in geotextiles.
\end{abstract}

Keywords: geomembrane, geotextile, puncture resistance

\section{INTRODUCTION}

Over the past few decades, experiences in the field of construction have shown that geosynthetics had become an excellent material supplementing or even replacing mineral substrates. They are successfully used to strengthen the substrate and retaining structures, sealing municipal and industrial waste landfills, separating materials of various grain sizes as well as stabilizing and protecting slopes against erosion (Cholewa, 2012; Girou, 2008; Hsieh, 2016; Jun Li, Xin-zhuang Cui et al., 2018).

凶e-mail:m.cholewa@ur.krakow.pl 
The application of geosynthetics significantly facilitates and accelerates earthworks, provided that they are used correctly (Messerklinger, 2014; Rankilor, 1981; PN-EN 14574: 2015-12). Due to the low resistance to UV rays and to puncture, they require compliance with the manufacturer's instructions during storage, transport, and installation.

\section{AIM AND SCOPE OF THE STUDY}

The purpose of this work was to perform and present the results of tests on the resistance of shielding and sealing geosynthetics to puncture. Standard qualification tests were carried out on a rigid support in accordance with PN-EN 14574: 2015-12. Four types of protective geotextiles with varying thicknesses and weights as well as three types of geomembranes differing in thickness were used in the testing. Individual materials were examined separately, as well as in the form of geocomposites, in which geomembranes and geotextiles were combined. A total of 19 material samples were tested in five replications, and the measurement results were averaged.

\section{MATERIAL AND METHODS}

Two groups of geosynthetics were used in the study. The first group comprised four types of geotextiles whose function is to separate materials with different grain sizes, or to provide filtration or shielding in engineering structures. Geotextiles were characterized by different thickness, basis weight, or production technology. The first and, at the same time, the thinnest geotextile was produced using a gluing process. Further three textiles were made using needle-punching technology. The second group consisted of imperme- able geomembranes with sealing properties, made of smooth-rolled polyethylene on both sides, with three grades of thickness: $1.0 ; 1.5$; and $2.0 \mathrm{~mm}$, respectively. They were produced in the process of rolling heated polyethylene. The parameters of individual geosynthetics are summarized in Table 1 below.

The set shown in Figures 1 and 2 was used to test the geosynthetics' resistance to pyramid puncture (PN-EN 14574: 2015-12).

The stand has been equipped with the following elements:

- aluminium plate,

- load pin with four sides and a $90^{\circ}$ point angle,

- electrical circuit consisting of an electric cell and a control lamp. The circuit signalled the moment at which the sample was punctured when the load pin came in contact with the aluminium plate.
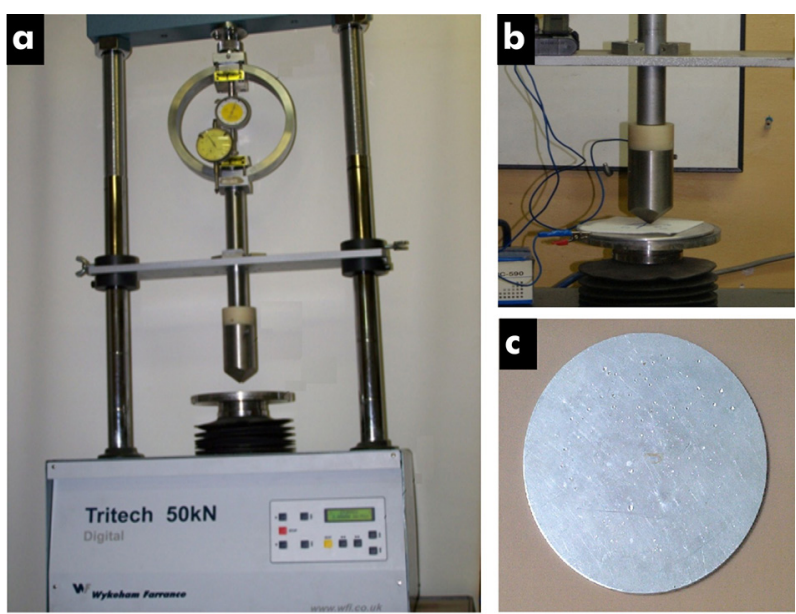

Fig. 1. Stand for testing puncture resistance of geosynthetics: a - weighing press (load pin), b - puncture pyramid, $\mathrm{c}$-aluminium plate

Table 1. Characteristics of the studied geosynthetics

\begin{tabular}{|c|c|c|c|c|c|c|c|c|}
\hline \multirow[t]{2}{*}{ Characteristic } & \multirow[t]{2}{*}{ Unit } & \multicolumn{4}{|c|}{ Geotextiles } & \multicolumn{3}{|c|}{ Geomembranes } \\
\hline & & Gw1 & Gw2 & Gw3 & Gw4 & Gmb1 & $\mathrm{Gmb} 2$ & Gmb3 \\
\hline Mass per unit area & $\mathrm{g} \cdot \mathrm{m}^{-2}$ & 330 & 300 & 90 & 500 & 300 & 450 & 600 \\
\hline $\begin{array}{l}\text { Thickness under external } \\
\text { pressure } 2 \mathrm{kPa}\end{array}$ & $\mathrm{mm}$ & 0.5 & 1.5 & 1.5 & 4.0 & 1.0 & 1.5 & 2.0 \\
\hline Production technique & - & Glued & Needle-punched & Needle-punched & Needle-punched & & alenderi & \\
\hline
\end{tabular}




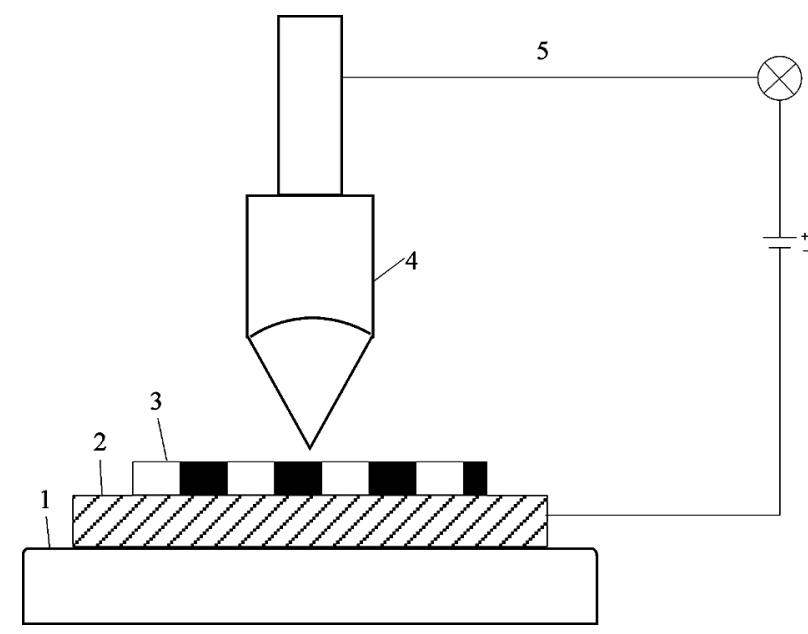

Fig. 2. Diagram of the set for testing puncture resistance of geosynthetics: 1 - base, 2 - aluminium plate, 3 -work sample, 4 - load pin, 5 - electrical circuit

The size of the punching force was measured using a ring dynamometer with a range of $0-30 \mathrm{kN}$, while a time sensor with a range of $0-20 \mathrm{~mm}$ was used to measure the displacement of the load pin.

The experiment was divided into stages. First, each geotextile and geomembrane were examined separately. Subsequently, in the next stage, their composites were created in the following order:
- Gmb1 geomembrane with geotextile (from Gw1 to Gw4),

- Gmb2 geomembrane with geotextile (from Gw1 to Gw4),

- $\mathrm{Gmb3}$ geomembrane with geotextile (from Gw1 to Gw4).

\section{TEST RESULTS}

\section{Geosynthetics tested separately}

The following results were obtained for geosynthetics that were punctured individually. Among geotextiles, the highest puncture strength, that is $0.44 \mathrm{kN}$, was obtained for needle-punched geotextile of $4 \mathrm{~mm}$ in thickness (Gw4). Twice lower value was achieved for glued geotextile (Gw1), despite its smallest thickness $(0.5 \mathrm{~mm})$, reaching the result of $0.19 \mathrm{kN}$. Needle-punched geotextiles with a thickness of $1.5 \mathrm{~mm}$ (Gw2 and Gw3) turned out to be the least resistant to puncture, reaching 0.17 and $0.13 \mathrm{kN}$, respectively.

Among the geomembranes, the values of puncture strength increased in proportion to the thickness of the geosynthetic, reaching successively: for Gmb1 $(1.0 \mathrm{~mm})-0.37 \mathrm{kN}$; for $\mathrm{Gmb} 2(1.5 \mathrm{~mm})-0.63 \mathrm{kN}$; and for $\mathrm{Gmb} 3(2.0 \mathrm{~mm})-1.14 \mathrm{kN}$.

Figures 3 and 4 below show the results that we have obtained.

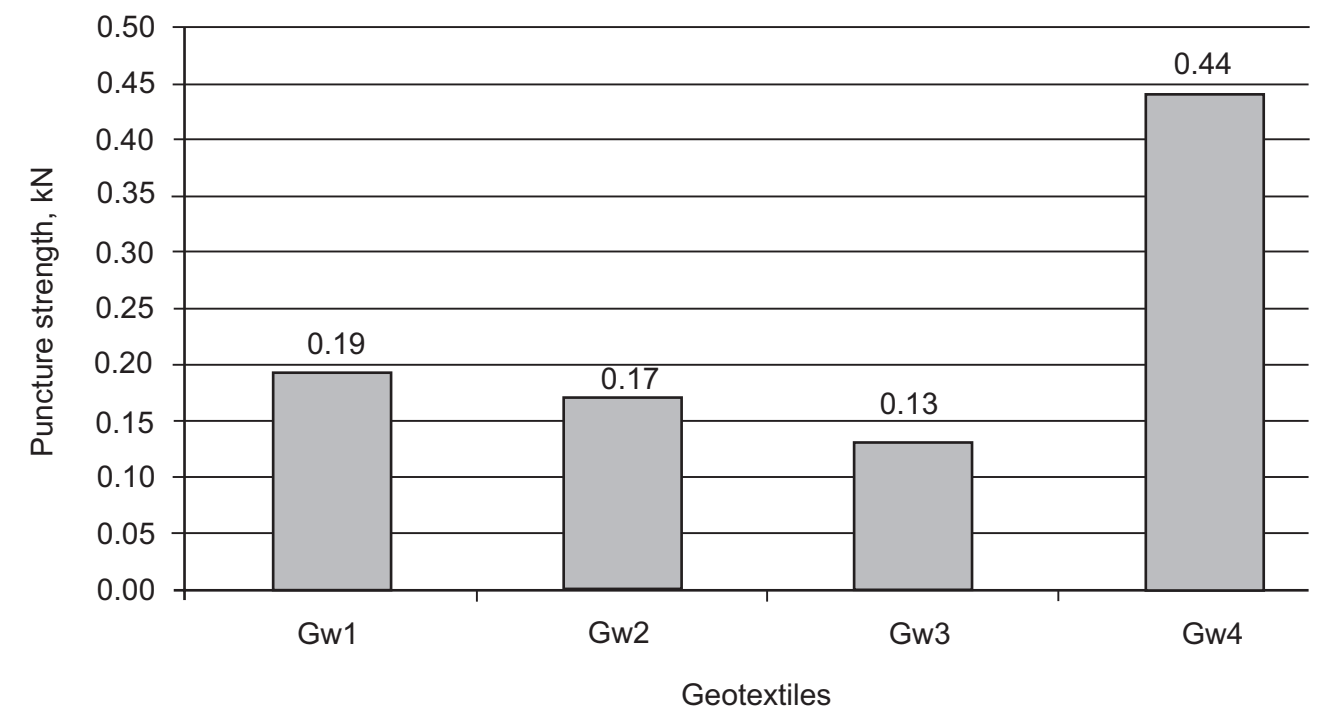

Fig. 3. Value of the puncture strength of geotextiles 


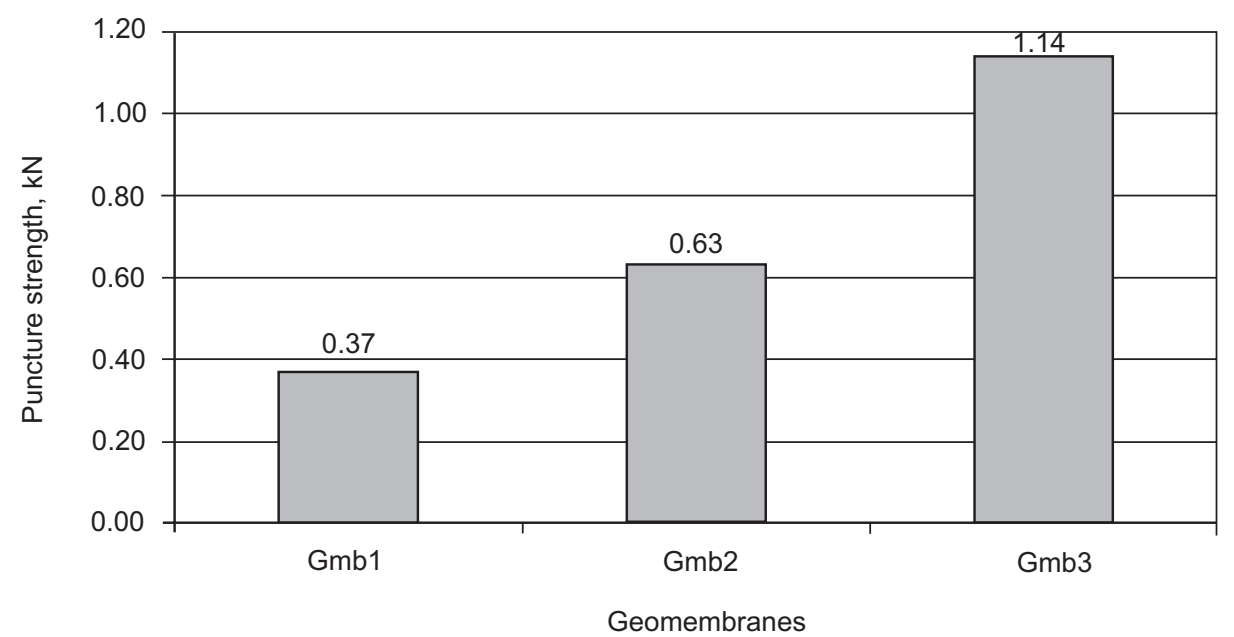

Fig. 4. Value of the puncture strength of geomembranes

\section{Geocomposites (composed of geomembranes and geotextiles)}

1 st group of geocomposites - geomembrane with the thickness of $1.0 \mathrm{~mm}(\mathrm{Gmb} 1)$ in a protective casing of geotextiles Gw1-Gw4 (see: Fig. 5)

Having investigated the first group of geocomposites, consisting of a $1.0 \mathrm{~mm}$ thick geomembrane $(\mathrm{Gmb} 1)$ in a casing made of successive geotextiles (Gw1-Gw4), we found that the composite with glued geotextile $(\mathrm{Gmb} 1+\mathrm{Gw} 1)$ achieved the highest puncture resistance at $1.31 \mathrm{kN}$, and the composite with the thickest needle-punched geotextile $(\mathrm{Gmb} 1+\mathrm{Gw} 4)$ at $1.30 \mathrm{kN}$. Among the composites with needle-punched $1.5 \mathrm{~mm}$ thick geotextiles, the combination with a heavier non-woven geotextile $(\mathrm{Gmb} 1+\mathrm{Gw} 2)$ turned out to be stronger, based on the resistance of $1.14 \mathrm{kN}$, whereas the lowest result was obtained by the geomembrane in combination with the Gw3 geotextile, reaching only $0.67 \mathrm{kN}$.

When comparing the achieved values with the results for the Gmb1 geomembrane itself, a significant increase in puncture resistance was found in favour of geocomposites (see: Fig. 5). For the geomembrane in a casing made of glued geotextile (Gw1) and needle-punched geotextile of the greatest thickness (Gw4), the value of the resistance was 3.5 times higher than the value of the geomembrane's puncture strength. The geomembrane combined with needle-punched geotextile, which was $1.5 \mathrm{~mm}$ thick and heavier (Gw2), achieved a 3-fold higher result. The lowest value was achieved for the geomembrane covered with needled geotextile, $1.5 \mathrm{~mm}$ thick, and $90 \mathrm{~g} \cdot \mathrm{m}^{2}$ weight (Gw3).

2nd group of geocomposites - geomembrane with the thickness of $1.5 \mathrm{~mm}(\mathrm{Gmb2})$ in a protective casing of geotextiles Gw1-Gw4 (see: Fig. 6)

Among geocomposites from the second group, the highest value of the breakthrough force $(1.81 \mathrm{kN})$ was obtained for the geomembrane in the casing made of the thickest geotextile (Gw4). Slightly lower values were achieved with glued geotextile $(1.67 \mathrm{kN})$ and needle-punched geotextile $1.5 \mathrm{~mm}(\mathrm{Gw} 2)$ with a higher basis weight $(1.58 \mathrm{kN})$. The least puncture-resistant composite in this group turned out to be a combination with a $1.5 \mathrm{~mm}$ thick geotextile, and a lower basis weight (Gw3), achieving a result of $1.06 \mathrm{kN}$.

Compared with the results for the Gmb2 geomembrane on its own (see: Fig. 6), a nearly 3-fold increase was obtained in the value of puncture resistance for the geomembrane in the casing made of needle-punched geotextile of the greatest thickness (Gw4); 2.7-fold increase for combination with glued geotextile (Gw1); and 2.5-fold increase in the case of a geomembrane with a needle-punched non-woven geotextile that was $1.5 \mathrm{~mm}$ thick and heavier (Gw2). A 1.7 times higher result was achieved for the geomembrane in a casing of needle-punched geotextile, $1.5 \mathrm{~mm}$ in thickness, and with less weight (Gw3). 


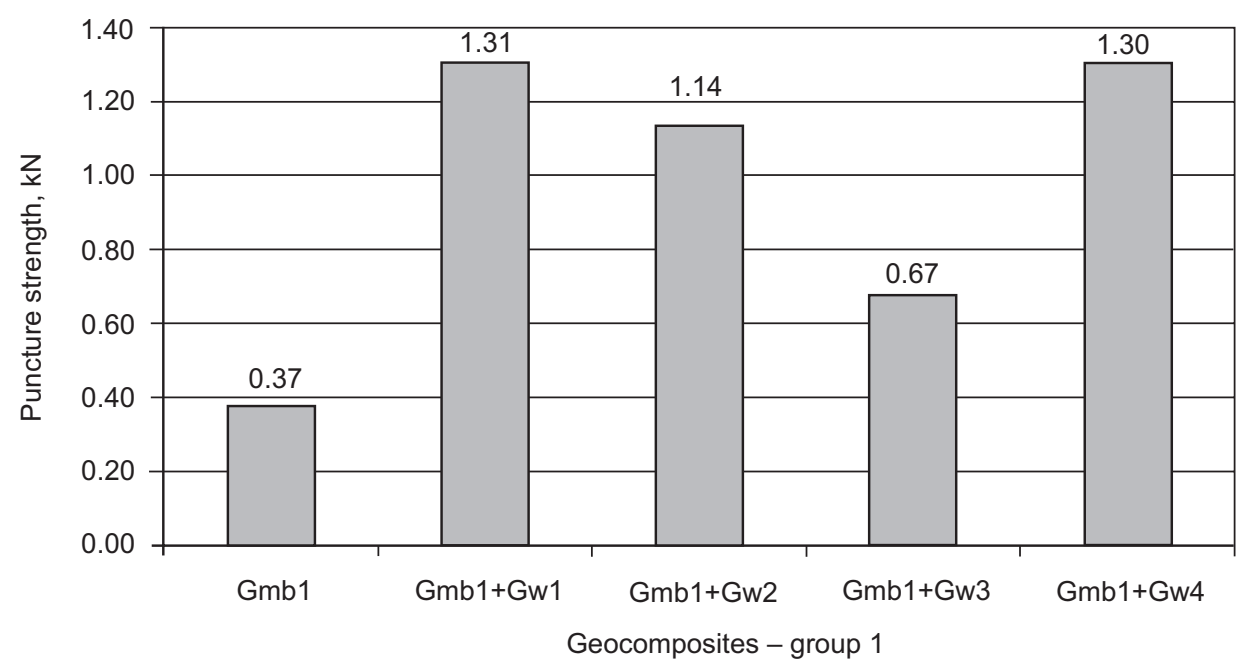

Fig. 5. Value of the puncture strength: 1 group - geomembrane Gmb1 in the casing of geotextiles Gw1-Gw4

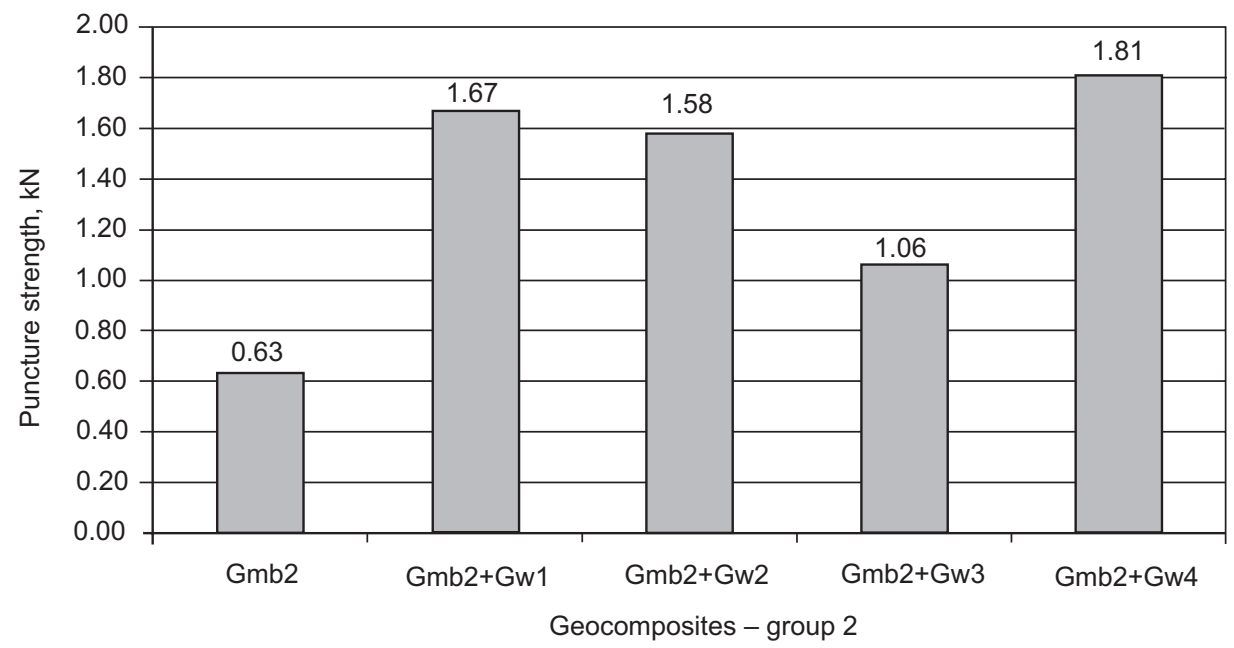

Fig. 6. Value of the puncture strength: 2 group - geomembrane Gmb2 in the casing of geotextiles Gw1-Gw4

3rd group of geocomposites - geomembrane with the thickness of $2.0 \mathrm{~mm}(\mathrm{Gmb3})$ in a protective casing of geotextiles Gw1-Gw4 (see: Fig. 7)

The last tested group was a combination of the thickest $2.0 \mathrm{~mm}$ geomembrane with subsequent geotextiles. As in the previous group, the highest value of the puncture resistance $(2.54 \mathrm{kN})$ was obtained by combining the geomembrane with needle-punched geotextile of the greatest thickness of Gw4 (see: Fig. 7). Geomembranes in a casing of heavier, $1.5 \mathrm{~mm}$ thick needle-punched geotextile (Gw2) obtained slightly lower results at $2.44 \mathrm{kN}$, as well as those in a casing of glued geotextile (Gw1) - $2.34 \mathrm{kN}$. The composite with Gw3 geotextile, with the value $1.65 \mathrm{kN}$, turned out to be the least resistant to puncture - just as in previous groups.

In relation to the results for the Gmb3 geomembrane, a two-fold increase in the value of the puncture resistance was recorded for geocomposites with a $4 \mathrm{~mm}$ needle-punched geotextile Gw4; a $1.5 \mathrm{~mm}$ 


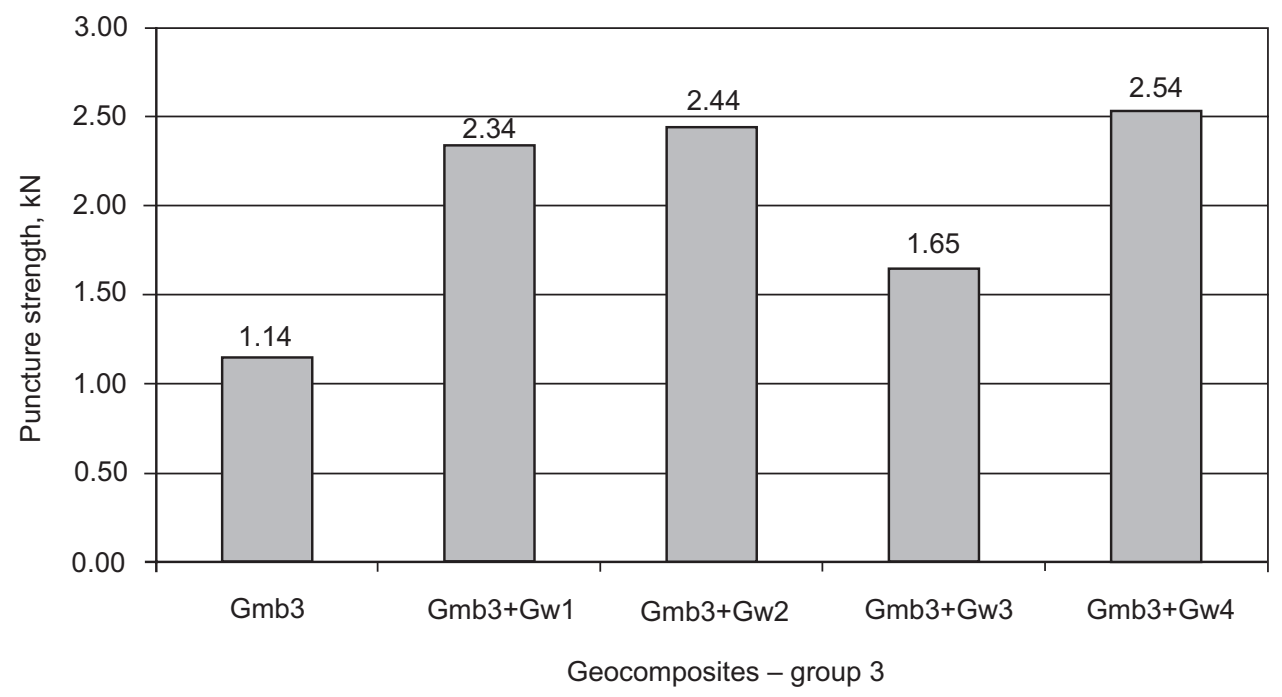

Fig. 7. Value of the puncture strength: 3 group - geomembrane Gmb3 in the casing of geotextiles Gw1-Gw4

heavier fabric geotextile (Gw2), and glued geotextile (Gw1). In turn, in the case of a geomembrane in a $1.5 \mathrm{~mm}$ thick needle-punched geotextile casing and lower basis weight (Gw3), the result was $45 \%$ higher.

\section{CONCLUSION}

Summing up the research results, it can be stated that the puncture resistance of geosynthetics increases as a result of combining them into composites. Among the geotextiles, needle-punched non-woven fabric with a thickness of $4 \mathrm{~mm}$ turned out to be the most resistant to puncture. The values for the remaining needle-punched geotextiles, $1.5 \mathrm{~mm}$ in thickness, depended on their basis weight, and differed in strength by $30 \%$ in favour of heavier geotextile. Glued geotextile with a thickness of $0.5 \mathrm{~mm}$ turned out to have similar strength to $1.5 \mathrm{~mm}$ geotextile with a heavier weight and to be $46 \%$ more durable than geotextile of the same thickness and a lower weight.

In the case of geomembranes, the puncture resistance turned out to be 2-5 times higher than the strength of geotextiles. The obtained results showed that the puncture resistance of this material increases linearly with its thickness, producing more than threefold increase in puncture strength at twice the thickness.

Geocomposites, i.e. materials that combine a geomembrane with a geotextile, turned out to be the most resistant to puncture. Their endurance grew together with the thickness of the geomembrane used. The best results were obtained for combinations between the geomembrane and the thickest needle-punched geotextile. Geocomposites with casings made of glued non-woven geotextile and needle-punched geotextile with higher basis weight achieved slightly lower and comparable values. Only geomembranes in a casing of needle-punched geotextile Gw3 were producing much lower results in comparison to the others. The above leads us to conclude that the best properties protecting against mechanical breakthrough are provided by combinations, in which the geomembrane occurs in a casing of the geotextile with larger thickness. High puncture resistance was also noted using glued geotextile. However, the combination with thin needle-punched geotextile with a low basis weight is not recommended for use in structures exposed to mechanical puncture.

The sum of the puncture strength of the geotextile and geomembrane tested separately is not equal to the strength of the composite formed from these two materials. There is an increase in puncture resistance in the contact area of the geotextile with the geomembrane. The fibres absorb the strength of the cone, therefore the increase in force needed to puncture the composite is $130 \%$ to $224 \%$ compared to the sum of the strength of geosynthetics tested separately. 
The presented test results can be used in the process of designing geosynthetic seals for municipal waste landfills. The insulating layer is often made of a geomembrane covered with a geotextile. The materials work together to produce greater puncture strength. This information is important for the designer.

\section{REFERENCES}

Cholewa, M. (2012). Wpływ wbudowania geomembrany oraz elementów drenujących na filtrację przez nasyp z mieszanki popioło-żużlowej. Infrastruktura i Ekologia Terenów Wiejskich. 2/IV, 105-115.

Girou, J. P. (2008). The Geosynthetics Discipline: Achievements and Challenges, Keynote Lecture, Proc. the First Pan American Geosynthetics Conference \& Exhibition, 2-5 March 2008, Cancun, Mexico, 1-3.
Hsieh, C.W. (2016). 23 - Geotextiles in agriculture and aquaculture. Editor(s): R.M. Koerner. Amsterdam: Woodhead Publishing.

Jun, Li, Xin-zhuang, Cui, Qing, Jin, Jun-wei, Su, She-qiang, Cui, Yi-lin, Wang (2018). Laboratory investigation of the durability of a new smart geosynthetic material. Construction and Building Materials, 169, 28-33.

Messerklinger, S. (2014). Failure of a geomembrane lined embankment dam - Case study. Geotextiles and Geomembranes, 42, 3, 256-266.

Rankilor, P. R. (1981). Membranes in Ground Engineering. Wiley, Chichester, United Kingdom.

PN-EN 13251:2002/A1:2006P. Geotekstylia i wyroby pokrewne - Właściwości wymagane w odniesieniu do wyrobów stosowanych w robotach ziemnych, fundamentowaniu i konstrukcjach oporowych.

PN-EN 14574:2015-12. Geosyntetyki - Wyznaczanie oporu na przebicie piramidką geosyntetyków osłonowych.

\section{ANALIZA WYTRZYMAŁOŚCI NA PRZEBICIE GEOMEMBRAN ORAZ GEOWŁÓKNIN}

\section{ABSTRAKT}

\section{Cel pracy}

Celem artykułu było przedstawienie wyników analizy wytrzymałości na przebicie geosyntetyków osłonowych i uszczelniających. Wykonano normowe badania kwalifikacyjne na sztywnym podparciu zgodnie z normą PN-EN 14574:2015-12. Do badań wykorzystano cztery rodzaje geowłóknin osłonowych o różnych grubościach i gramaturach oraz trzy rodzaje geomembran różniących się grubością. Poszczególne materiały zostały zbadane oddzielnie oraz w formie geokompozytów, w których połączono geomembrany z geowłókninami.

\section{Materiat i metody}

W badaniu zastosowano dwie grupy geosyntetyków. Pierwszą grupą były cztery rodzaje geowłóknin, których funkcją jest rozdzielanie materiałów o różnym uziarnieniu, filtracja lub osłona w konstrukcjach inżynierskich. Geowłókniny charakteryzowały się różną grubością, gramaturą lub technologią wytwarzania. Drugą grupą były nieprzepuszczalne geomembrany o właściwościach uszczelniających, wykonane z polietylenu obustronnie walcowanego na gładko, o trzech grubościach. Do przeprowadzenia badania wytrzymałości geosyntetyków na przebicie piramidką (PN-EN 14574:2015-12).

\section{Wyniki i wnioski}

Wśród geowłóknin najbardziej odporną na przebicie okazała się gowłóknina igłowana o grubości $4 \mathrm{~mm}$. Wartości dla pozostałych geowłóknin igłowanych o grubości $1,5 \mathrm{~mm}$ zależały od ich gramatury i różniły się wytrzymałością o 30\% na korzyść geowłókniny o większej gramaturze. Geowłóknina klejona o grubości $0,5 \mathrm{~mm}$ okazała się mieć zbliżoną wytrzymałość do $1,5 \mathrm{~mm}$ geowłókniny o większej gramaturze i o $46 \%$ bardziej wytrzymałą niż geowłóknina o takiej samej grubości i mniejszej gramaturze. W przypadku geomembran wytrzymałość na przebicie okazała się być 2-5-krotnie większa niż wytrzymałość geowłóknin.

Słowa kluczowe: geowłóknina, geomembrana, wytrzymałość na przebicie 